\title{
Effect of Denervation on the Expression of Two Glucose Transporter Isoforms in Rat Hindlimb Muscle
}

Nancy E. Block, ${ }^{* *}$ Donald R. Menick, ${ }^{* 5}$ Katherine A. Robinson, ${ }^{*}$ and Maria G. Buse*:

Divisions of ${ }^{*}$ Endocrinology, Metabolism and Nutrition and ${ }^{\ddagger}$ Cardiology, Department of Medicine, Gazes Cardiac Research Institute, and ${ }^{\S}$ Department of Biochemistry and Molecular Biology, Medical University of South Carolina, Charleston, South Carolina 29425

\begin{abstract}
Denervation rapidly (within $24 \mathrm{~h}$ ) induces insulin resistance of several insulin-responsive pathways in skeletal muscle, including glucose transport; resistance is usually maximal by $3 \mathrm{~d}$. We examined the effect of denervation on the expression of two glucose transporter isoforms (GLUT-1 and GLUT-4) in rat hindlimb muscle; GLUT-4 is the predominant species in muscle. 1 d postdenervation, GLUT-1 and GLUT-4 mRNA and protein concentrations were unchanged. 3 and 7 d postdenervation, GLUT- 4 mRNA and protein (per microgram DNA) were decreased by $50 \%$. The minor isoform, GLUT-1 mRNA increased by $\sim 500$ and $\sim 100 \%$, respectively, on days 3 and 7 while GLUT-1 protein increased by $\sim 60$ and $\sim 100 \%$. The data suggest that the insulin resistance of glucose transport early after denervation does not reflect a decrease in total glucose transporter number; however, decreased GLUT- 4 expression may contribute to its increased severity after $3 \mathrm{~d}$. Parallel decreases in GLUT-4 mRNA and GLUT-4 protein postdenervation are consistent with pretranslational regulation; GLUT-1 expression may be regulated pre- and posttranslationally. The cell type(s) which overexpress GLUT-1 postdenervation need to be identified. Nervous stimuli and/or contractile activity may modulate the expression of GLUT-1 and GLUT- 4 in skeletal muscle tissue. (J. Clin. Invest. 1991. 88:1546-1552.) Key words: glucose transporters 1 and $4 \cdot$ mRNA and protein expression • insulin resistance $\bullet$ skeletal muscle
\end{abstract}

\section{Introduction}

The transport of glucose into most mammalian cells occurs by facilitated diffusion, and is mediated by a multigene family of transmembrane glycoproteins (reviewed in reference 1). Five distinct isoforms of mammalian facilitative glucose transporters differing in their tissue distribution and putative functional properties have been cloned. Each member shares 40-60\% overall amino acid homology, with the putative transmem-

Address correspondence to Dr. Maria G. Buse, Department of Medicine, Division of Endocrinology, Metabolism and Nutrition, Medical University of South Carolina, 171 Ashley Avenue, Charleston, SC 29425.

Dr. Block's current address is Cecil B. Day Neuromuscular Research Laboratory, Massachusetts General Hospital, 149 The Navy Yard, 13th Street, Charlestown, MA 02129.

Received for publication 7 November 1990 and in revised form 27 June 1991.

J. Clin. Invest.

(C) The American Society for Clinical Investigation, Inc.

$0021-9738 / 91 / 11 / 1546 / 07 \$ 2.00$

Volume 88, November 1991, 1546-1552 brane $\alpha$-helical domains containing the regions of highest homology.

In view of its mass, skeletal muscle is a critical site of glucose homeostasis. Insulin stimulates glucose transport into skeletal muscle, cardiac muscle, and adipose tissue by promoting the translocation of glucose transporters from an intracellular pool to the plasma membrane and by increasing their intrinsic activity (reviewed in references 2 and 3 ). These tissues express two known glucose transporter isoforms; GLUT-1 and GLUT$4^{1}$ (1). GLUT-1 (also known as the HepG2 or erythroid/brain glucose transporter [2]) is distributed ubiquitously among tissues, is located primarily in the plasma membrane and is believed to be responsible mainly for basal glucose uptake. Conversely, GLUT-4 (the muscle/fat glucose transporter [2]) is expressed only in the above-mentioned insulin-sensitive tissues, and is located predominantly in intracellular vesicles which translocate to the plasma membrane in response to insulin.

Denervation of skeletal muscle rapidly induces insulin resistance involving multiple insulin-sensitive pathways, including glucose transport (4-6). Insulin binding $(4,7)$, insulin receptor activation (7), circulating insulin, and glucose levels are unaffected and the effects of denervation can be mimicked by immobilization (8). The role of the glucose transporter in postdenervation insulin resistance has not been addressed.

Levels of both GLUT-1 and GLUT-4 mRNA and protein can be regulated by several stimuli (reviewed in references 3 and 9). GLUT-1 mRNA expression in rodent fibroblasts, brain, or neuronal cells is increased by growth factors (10-14), glucose deprivation (15), and cellular transformation $(12,16$, 17). GLUT-4 mRNA and protein decrease in adipocytes (18$21)$ and to a lesser extent in muscles $(3,19,22)$ of rats with insulinopenic diabetes; whereas in fasted rats GLUT-4 expression is decreased in adipocytes $(20,21,23)$ and increased in muscle (23). In this paper we examined the effect of denervation on the total expression of GLUT-1 and GLUT-4 in rat hindlimb muscles.

\section{Methods}

Materials. A specific polyclonal rabbit antibody raised against a synthetic dodecapeptide, representing the deduced carboxylterminal sequence of rat muscle GLUT-4 (24) was a generous gift of Dr. Amira Klip (University of Toronto). A site-directed polyclonal rabbit antibody against a polypeptide corresponding to the $\mathrm{COOH}$-terminus of rat brain, GLUT-1 $(25,26)$, was purchased from East-Acres Biologicals (Southbridge, MA). DNA polymerase I (Klenow fragment) and restriction enzymes were purchased from Promega Biotec (Madison, WI), polynucleotide kinase from New England Biolabs (Beverly, MA), [ $\gamma$ -

1. Abbreviations used in this paper: ECL, enhanced chemiluminescence; FGF, fibroblast growth factor; GLUT-1 and GLUT-4, glucose transporter isoforms 1 and 4; TBST, $50 \mathrm{mM}$ Tris, $150 \mathrm{mM} \mathrm{NaCl}$, $0.05 \%$ Tween 20 . 
$\left.{ }^{32} \mathrm{P}\right] \mathrm{ATP}$ and $\left[\alpha-{ }^{32} \mathrm{P}\right] \mathrm{dCTP}$ from Dupont-New England Nuclear (Boston, MA). All other materials were reagent grade and were purchased from commercial sources.

Animals. Male Wistar BR rats (Charles River Laboratories, Wilmington, MA) weighing 120-150 g were allowed access to standard rodent chow and water ad libitum throughout the experiment. They were anesthetized by inhalation of methoxyflurane (Metofane; Pittman-Moore, Washington Crossing, NJ) before surgery, when a $\sim 3$ $\mathrm{mm}$ section of the sciatic nerve from one leg was excised above the knee (denervated). The contralateral control leg was either not operated or sham operated.

1,3 , or $7 \mathrm{~d}$ after unilateral denervation, gastrocnemius and soleus muscles from both hindlimbs were excised from anesthetized rats, immediately frozen in liquid nitrogen and pulverized in a mortar at $-70^{\circ} \mathrm{C}$. Total RNA, DNA, or cell membranes were isolated from the frozen powder as described below. In some experiments, kidney, liver, brain, and epidymal fat pads were also removed, frozen, and RNA or membranes prepared for analysis.

Extraction and quantitation of RNA and DNA. RNA was isolated by the acid guanidinium thiocyanate-phenol-chloroform extraction method of Chomczynski and Sacchi (27). Quantity and purity of RNA was assessed by UV absorbance at 260 and $280 \mathrm{~nm}$; the $260 / 280$ absorbance ratio was typically 1.8 . DNA was extracted and quantified using a modification of the Burton assay (28).

Northern blot analysis. RNA $(30 \mu \mathrm{g})$ was denatured by heating to $65^{\circ} \mathrm{C}$ for $10 \mathrm{~min}$ in $50 \%$ formamide, separated by electrophoresis on $1 \%$ agarose-formaldehyde gels and transferred to nylon membranes (Gene Screen; Dupont-New England Nuclear). Quantity and integrity of RNAs were confirmed by staining with ethidium bromide.

The probes used for analysis of glucose transporter mRNAs were a 436-bp Bam HI fragment from rat brain GLUT-1 cDNA (25) (prGT$\mathrm{B} 436 \mathrm{H} 2$ ) and a 2-kb Sal I fragment from human GLUT-4 cDNA (pGEN4Z-AMT [29]). Both plasmids were generous gifts of Dr. Graeme I. Bell (University of Chicago). The cDNA fragments were labeled with $\left[\alpha_{-}{ }^{32} \mathrm{P}\right] \mathrm{dCTP}$ by random primer extension (30). Blots were hybridized at $42^{\circ} \mathrm{C}$ in $50 \%$ formamide, $10 \times$ Denhard's solution, $1 \%$ SDS, $50 \mathrm{mM}$ Tris- $\mathrm{HCl}, \mathrm{pH} 7.5,1 \mathrm{M} \mathrm{NaCl}, 0.1 \% \mathrm{Na}_{4} \mathrm{P}_{2} \mathrm{O}_{7}$, and 100 $\mu \mathrm{g} / \mathrm{ml}$ salmon sperm DNA, washed at $52^{\circ} \mathrm{C}$ with $0.1 \times$ SSC $(1 \times$ SSC $=150 \mathrm{mM} \mathrm{NaCl}$ and $15 \mathrm{mM}$ sodium citrate) and $1 \%$ SDS, and autoradiographed.

For identification of $\alpha$-skeletal muscle actin mRNA an oligonucleotide corresponding to residues $138-161$ of the rat $\alpha$-skeletal muscle actin mRNA 3' untranslated region (31) was synthesized on an Applied Biosystems DNA synthesizer, end labeled with $\left[\gamma-{ }^{32} \mathrm{P}\right] \mathrm{ATP}$, and hybridized to blots at $37^{\circ} \mathrm{C}$ as above but omitting formamide. Blots were washed at $37^{\circ} \mathrm{C}$ in $2 \times \mathrm{SSC}$ and $1 \%$ SDS. Autoradiograms were quantified by computer assisted densitometry of digital images.

Quantitation of glucose transporter proteins by immunoblotting. The procedure used for preparation of cellular membranes was essentially that of Klip et al. (32) for total membrane preparations, modified as suggested by Dr. Jeffrey Pessin (personal communication). Briefly, $0.5 \mathrm{~g}$ of frozen, powdered muscle or brain was homogenized (Polytron) for $5 \mathrm{~s}$ at low speed, at $4^{\circ} \mathrm{C}$ with $10 \mathrm{vol}$ of buffer $\mathrm{A}(0.25 \mathrm{M}$ sucrose, 10 $\mathrm{mM}$ Tris $\mathrm{HCl} \mathrm{pH} \mathrm{7.4,2} \mathrm{mM} \mathrm{EDTA).} \mathrm{After} \mathrm{centrifugation} \mathrm{at} \mathrm{3,700} \mathrm{g}$ for $25 \mathrm{~min}$ at $4^{\circ} \mathrm{C}$, the supernatant was mixed with an equal volume of buffer A containing $1.6 \mathrm{M} \mathrm{KCl}$ at $4^{\circ} \mathrm{C}$ for $30 \mathrm{~min}$, then centrifuged for $90 \mathrm{~min}$ at $200,000 \mathrm{~g}$. The pellet was resuspended in buffer $\mathrm{A}$ and the protein concentration measured by the Bradford assay (33) (protein assay; Bio-Rad Laboratories, Inc., Richmond, CA) against bovine $\gamma$-globulin standards.

Proteins ( $100 \mu \mathrm{g}$ for GLUT-1 assays and $50 \mu \mathrm{g}$ for GLUT -4$)$ were solubilized for $20 \mathrm{~min}$ at $24^{\circ} \mathrm{C}$ in Laemmli's sample buffer containing $2 \%$ SDS (34), separated by SDS-PAGE under reducing conditions on a $10 \%$ polyacrylamide resolving gel and $3 \%$ stacking gel, then transferred onto nitrocellulose membranes $(0.45 \mu \mathrm{m}$ Trans Blot; Bio-Rad Laboratories, Inc.) at $210 \mathrm{~mA}, 24^{\circ} \mathrm{C}, 4 \mathrm{~h}$. Blots were blocked for $1 \mathrm{~h}$ at $24^{\circ} \mathrm{C}$ in $50 \mathrm{mM}$ Tris pH 7.4, $150 \mathrm{mM} \mathrm{NaCl}, 0.05 \%$ Tween 20 (TBST) containing $5 \%$ nonfat dry milk (Carnation), and then incubated for $16 \mathrm{~h}$ at $4^{\circ} \mathrm{C}$ in TBST containing 3\% fatty acid free BSA and the specific antisera to GLUT-1, to GLUT-4 or nonimmune rabbit serum, each diluted 1:500. Membranes were washed three times with TBST, then incubated for 2 $\mathrm{h}$ at $24^{\circ} \mathrm{C}$ in TBST with $3 \%$ BSA and ${ }^{125} \mathrm{I}$-goat antirabbit IgG $(0.2$ $\mu \mathrm{Ci} / \mathrm{ml}$; ICN, Cambridge, MA) and after extensive washing with TBST, autoradiographed on X-OMAT AR film (Eastman Kodak Co., Rochester, NY). Labeled bands corresponding to the glucose transporter protein and adjacent bands without specific labeling (background) were excised and the radioactivity quantified in a $\gamma$-counter; specific counts associated with the bands of interest were determined by substracting background activity.

In some experiments, immunoblots of GLUT-4 were developed by a modified procedure, i.e., incubations with anti-GLUT-4 antibody were carried out in TBST containing $5 \%$ nonfat milk, and ${ }^{125} \mathrm{I}$-goat antirabbit IgG was replaced by horseradish peroxidase-labeled goat antirabbit IgG (Chemicon International, El Segundo, CA) to which the blots were exposed for $1 \mathrm{~h}$ at $24^{\circ} \mathrm{C}$, washed six times in TBST, developed with the enhanced chemiluminescence (ECL) Western blotting detection system (Amersham International, Amersham, UK), followed immediately by several sequential exposures to $\mathrm{x}$-ray film (X-OMAT $R P)$ lasting $10 \mathrm{~s}$ to $5 \mathrm{~min}$. Bands of interest on the autoradiogram were quantified by computer-assisted densitometry of digital images. Glucose transporter concentrations per unit protein were analyzed as ratios of denervated/control muscle in all studies. Because essentially identical results were obtained with the two methods, we pooled quantitative data.

Statistical analysis. Means \pm SE are shown. The significance of differences between means was analyzed by $t$ test or by paired $t$ test.

\section{Results}

GLUT-1 and GLUT-4 mRNA expression. The tissue-specific expression of GLUT-1 and GLUT-4 mRNA was confirmed by hybridization of CDNA probes to total RNA isolated from rat skeletal muscle, epididymal fat, kidney, brain, and liver (data not shown). GLUT-1 cDNA hybridized to RNA from each tissue except for liver, which expresses almost exclusively GLUT-2 (1); with the highest levels of GLUT-1 detected in kidney and brain $(1,35)$. Of the tissues studied, hybridization of GLUT-4 was detected only in skeletal muscle and epididymal fat $(1,28)$.

Glucose transporter mRNA was assessed in rat calf muscles 1, 3, and $7 \mathrm{~d}$ after unilaterally severing the sciatic nerve (Fig. 1). In sham-operated and nonoperated contralateral muscles GLUT-1 and GLUT-4 mRNA abundance was unchanged and similar to that in nondenervated rats (data not shown). Because the effects of denervation were similar when compared to nonoperated or sham-operated contralateral hindlimb muscles, data from all control muscles were pooled and compared to denervated muscles at similar time points for statistical analysis. Comparison of glucose transporter mRNA levels from equal amounts of total RNA revealed no significant difference in GLUT-1 and 4 message abundance between $1 \mathrm{~d}$ denervated or control muscles (Figs. 1 and 2). However, $3 \mathrm{~d}$ after denervation, GLUT -4 mRNA was consistently reduced $(\sim 50 \%, P$ $<0.01$ vs. controls), and GLUT-1 mRNA was increased approximately sixfold $(P<0.01)$. By 1 wk after denervation, these effects appeared to be diminished; GLUT-1 mRNA was still increased, but only approximately twofold $(P<0.01)$ and GLUT-4 mRNA was $\sim 70 \%$ of control values $(P<0.05)$.

Because denervation causes muscle atrophy, hindlimb muscle DNA content was measured as an indicator of cell number (36) in a separate group of unilaterally denervated rats (Table I). $3 \mathrm{~d}$ postdenervation, the DNA concentration per gram 


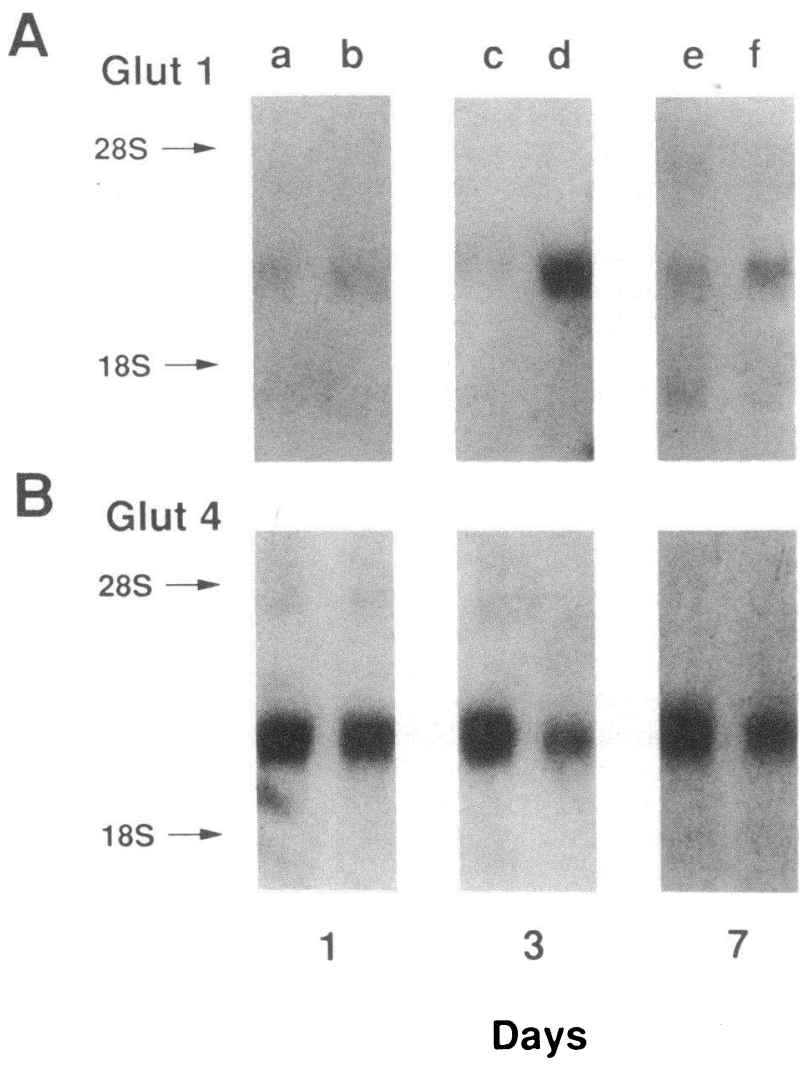

Figure 1. Effect of denervation on glucose transporter mRNA expression. Total RNA was isolated as described in Table I from hindlimb muscles of unilaterally sciatotomized rats, and separated by electrophoresis on $1 \%$ agarose (30 $\mu \mathrm{g} \mathrm{RNA/lane).} \mathrm{Northern} \mathrm{blots} \mathrm{were}$ hybridized with ${ }^{32} \mathrm{P}$-labeled cDNA probes to GLUT-1 $(A)$ or GLUT-4 $(B)$, washed, and autoradiographed as described in Methods. Denervated muscles (lanes $b, d, f)$; Control muscles $(a, c, e), 1,3$, or $7 \mathrm{~d}$ after surgery.

muscle, was slightly increased, but not significantly different from controls. However, after $7 \mathrm{~d}$, DNA was increased by $\sim 30 \%$ in denervated muscles $(P<0.01)$. Total RNA content (per gram muscle) was not affected by denervation at any time point (Table I). Therefore, the RNA/DNA ratio was decreased $\sim 8$ and $\sim 30 \% 3$ and $7 \mathrm{~d}$ after denervation, respectively. The effects of denervation on GLUT-1 and GLUT-4 mRNA after 3 d were similar whether evaluated based on total DNA or total RNA. GLUT-1 and GLUT-4 mRNA levels (per microgram DNA), were $\sim 172$ and $\sim 56 \%$ of controls, respectively, $7 \mathrm{~d}$ after denervation (Fig. 2). Thus, when expressed on a per cell basis, GLUT-4 mRNA was reduced similarly 3 and $7 \mathrm{~d}$ after denervation, whereas the increase in GLUT-1 expression observed on day 3 tended to return towards control values by day 7. Assuming similar labeling efficiencies for the two probes (which were labeled to similar specific activities), the ratio of GLUT- 1 to GLUT- 4 mRNA was $\sim$ 1:20 in control muscles compared to $\sim 1: 23 \mathrm{~d}$ postdenervation. $\alpha$-Skeletal muscle actin mRNA levels were not significantly changed 1 day after denervation, but decreased slightly $(\sim 30 \%)$ after $3 \mathrm{~d}$. Actin mRNA per cell was reduced to nearly half of control values 1 wk after denervation.

Immunoblots of GLUT-1 and GLUT-4 protein. The abundance of glucose transporter proteins in muscle membranes was estimated 1, 3, and $7 \mathrm{~d}$ after unilateral denervation (Fig. 3 and Table II). Protein recovery in the total membrane pellet was $0.94 \pm 0.03 \mathrm{mg} / \mathrm{g}$ muscle wet wt $(n=39)$ in control muscles and there was no significant difference in protein yield per gram tissue between control and denervated muscles at any time point. The GLUT-1 signal in our Western blots was much

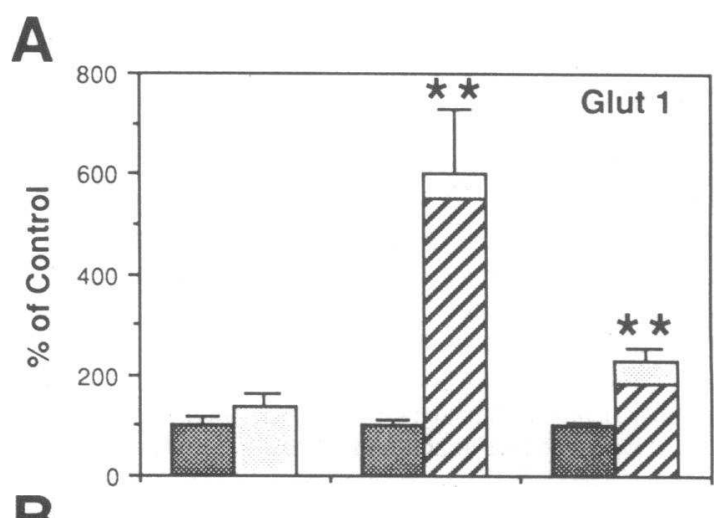

B

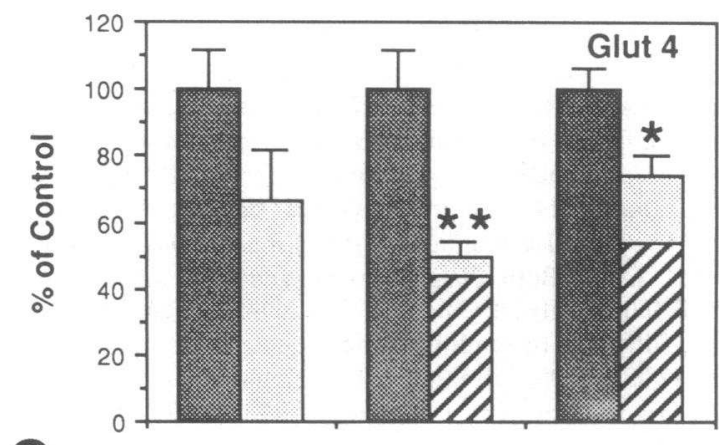

C

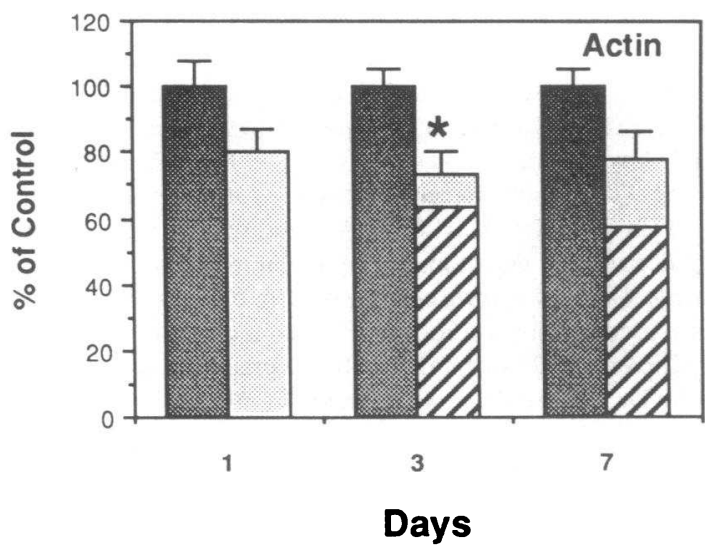

Figure 2. Effect of denervation on relative amounts of glucose transporter mRNAs. RNA and DNA isolation, and Northern blot analyses were performed as described in legends to Fig. 1 and Table I. $\alpha$-Skeletal muscle actin mRNA was identified as a $\sim 2$-kb band after autoradiography of blots hybridized with a ${ }^{32} \mathrm{P}$ end-labeled synthetic oligonucleotide as described in Methods. mRNA was quantified from autoradiograms by computer-assisted densitometry of digital images. Values for denervated muscle are shown relative to contralateral controls (dark stippled bars) and were normalized to RNA (light stippled bars) or DNA (hatched bars). Values represent means \pm SE for 4-12 muscles/group. ${ }^{*} P<0.05 ;{ }^{* *} P<0.01$ vs. control by $t$ test. Statistical analyses and SE shown pertain to values expressed per microgram RNA. 
Table I. Effect of Denervation on RNA and DNA Content of Hindlimb Skeletal Muscle

\begin{tabular}{lcccc}
\hline & \multicolumn{4}{c}{ Days after denervation } \\
\cline { 2 - 4 } & 1 & 3 & 7 \\
\hline RNA $(\mu g / g)$ & & & \\
Control & $1080 \pm 115(6)$ & $1100 \pm 63(12)$ & $919 \pm 56 \quad(6)$ \\
Denervated & $955 \pm 107(6)$ & $977 \pm 40(13)$ & $945 \pm 114(6)$ \\
DNA $(\mu g / g)$ & & & & \\
Control & - & $645 \pm 33(4)$ & $613 \pm 26 \quad(4)$ \\
Denervated & - & $699 \pm 45(4)$ & $812 \pm 22 \quad(4)^{*}$ \\
& & & & \\
\hline
\end{tabular}

Rats were unilaterally sciatotomized 1,3 , and $7 \mathrm{~d}$ before experiments. The contralateral control leg was either not operated or sham operated. Hindlimb (soleus and gastrocnemius) muscles were removed under anesthesia, immediately frozen and DNA and RNA extracted and quantitated as described in Methods. Data represent means \pm SE (n/group). ${ }^{*} P<0.01$ vs. control.

weaker than that of GLUT-4. In experiments where immunoblots of GLUT-1 and GLUT-4 of the same membrane preparation were performed by the identical procedure and specifically bound ${ }^{125} \mathrm{I}$-IgG was quantitated by $\gamma$-counting, the specific radioactivity (per microgram protein) associated with the glucose transporter in control muscles was $14.2 \pm 2.8$-fold greater after exposure to the antibody specific for GLUT-4 than after exposure to anti-GLUT-1 antibody $(n=6)$. However, because the two antibodies may display different binding kinetics, the relative abundance of the two glucose transporter isoforms in mus-

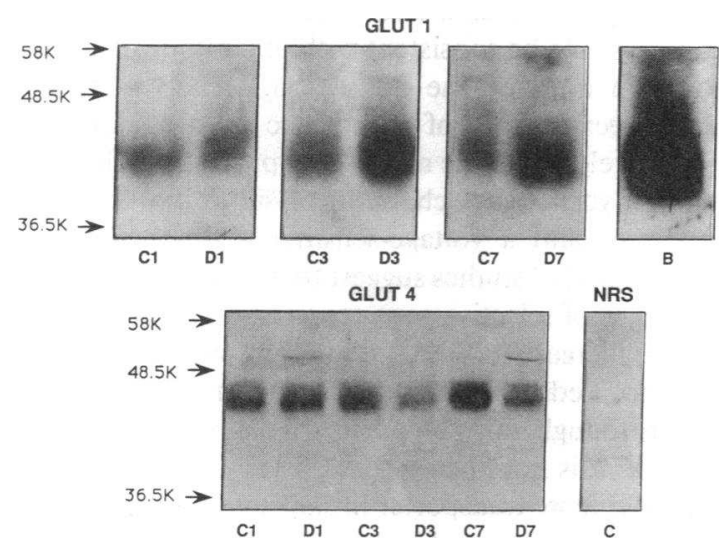

Figure 3. Effect of denervation on glucose transporter proteins. Total muscle membrane preparations from control $(C)$ and denervated $(D)$ hindlimb muscles were prepared 1,3 , and $7 \mathrm{~d}$ after surgery. For analyses of GLUT-1, $100 \mu \mathrm{g}$ and for GLUT-4, $50 \mu \mathrm{g}$ membrane proteins from $C$ and $D$ were separated on SDS-PAGE, transferred onto nitrocellulose, and incubated with specific antibodies to the carboxyl termini of GLUT-1 or GLUT-4 or nonimmune rabbit serum (NRS). The GLUT-1 blot also shows $50 \mu \mathrm{g}$ brain membranes $(B)$ for comparison. GLUT-1 immunoblots were developed with ${ }^{125}$ I-antirabbit $\gamma$-globulin and autoradiographed, the blot shown was exposed to $\mathrm{X}$ OMAT AR film for $24 \mathrm{~h}$ with a Dupont Lightening + intensifying screen. GLUT-4 immunoblots were developed with the same procedure or with the ECL method described in Methods. The GLUT-4 immunoblot shown was developed with the ECL method and was exposed to X-OMAT RP film for $5 \mathrm{~min}$. Prestained molecular weight standards (Sigma Chemical Co.) shown are $\left(\times 10^{-3}\right)$ : pyruvate kinase, 58; fumarase, 48.5 ; lactic dehydrogenase, 36.5 .
Table II. Effect of Denervation on the Concentration of Immunoreactive Glucose Transporter Proteins in Total Muscle Membrane Preparations

\begin{tabular}{llc}
\hline \multirow{2}{*}{$\begin{array}{c}\text { Days after } \\
\text { denervation }\end{array}$} & \multicolumn{2}{c}{$\begin{array}{c}\text { Immunoreactive glucose transporter } \\
\text { protein \% of contralateral control muscle }\end{array}$} \\
\cline { 2 - 3 } Normalized to Protein & \multicolumn{1}{c}{ GLUT-1 } & GLUT-4 \\
1 & $131 \pm 22(5)$ & $91 \pm 15(6)$ \\
3 & $172 \pm 12(12)^{*}$ & $48 \pm 9(9)^{*}$ \\
7 & $257 \pm 36(7)^{*}$ & $63 \pm 12(6) \ddagger$ \\
Normalized to Muscle DNA & & \\
3 & $159 \pm 11(12)^{*}$ & $44 \pm 8(9)^{*}$ \\
7 & $194 \pm 27(7)^{*}$ & $48 \pm 9(6)$ \\
\hline
\end{tabular}

Muscle membranes from control and denervated hindlimb muscles were prepared, separated by SDS-PAGE, transferred to nitrocellulose membranes and incubated with specific antibodies to the carboxyl termini of GLUT-1 or GLUT-4, developed and quantitated as described in Fig. 3 and in Methods. Equal amounts of control and denervated muscle membrane proteins from the same rat were applied to gel, $50 \mu \mathrm{g}$ for analyses of GLUT-4 and $100 \mu \mathrm{g}$ for GLUT-1. The data shown are expressed as ratios of (denervated/control) $\times 100$, normalized to protein or to DNA/g muscle (from Table I). (n), number of muscle preparations from separate rats. ${ }^{*} P<0.01$ vs. control; $\ddagger P<0.05$ vs. control.

cle cannot be extrapolated from these data. The method is useful, however, in quantifying relative changes in the abundance of either isoform in response to stimuli, i.e., denervation.

$1 \mathrm{~d}$ denervation did not affect the concentration of either GLUT-1 or GLUT-4 protein in skeletal muscle. Based on equal amounts of membrane protein, GLUT-1 was $\sim 70$ and $150 \%$ more abundant in muscles 3 and $7 \mathrm{~d}$ after denervation, respectively, than in controls. Based on DNA, GLUT-1 protein was increased by 60 and $90 \%$ vs. controls, 3 and $7 \mathrm{~d}$ after denervation, respectively. This increase is much less than that observed with GLUT-1 mRNA, which increased by $\sim 500 \% 3 \mathrm{~d}$ after denervation (Fig. 2), suggesting that GLUT-1 protein content in skeletal muscle reflects in part regulation distal to transcription. In contrast, GLUT-4 protein expression (Fig. 3 and Table II) paralleled that of GLUT-4 mRNA (Fig. 2); based on muscle DNA both GLUT-4 protein and mRNA abundance was reduced by $\sim 50 \% 3$ and 7 days after denervation.

\section{Discussion}

Reduced insulin-stimulated glucose transport has been observed in vivo as early as $3 \mathrm{~h}$ after denervating rat hindlimb muscles (6) and in in vitro transport assays carried out $24 \mathrm{~h}$ after denervation in vivo $(4,37,38)$, a time when we did not observe significant changes in transporter message or protein levels. The in vitro studies of glucose transport involved brief $(\sim 60$-min) incubations of soleus and extensor digitorum longus muscles (4), which were isolated from rats younger than those used in the present studies; whereas in vivo transport assays (6) utilized rats which were somewhat older than those used here. The method of denervation, i.e., sciatotomy, was identical in each study, and the early impairment of insulin stimulated glucose transport after denervation was demonstrable in both fast-twitch and slow-twitch muscles $(4,6)$. The time 
of onset and the severity of insulin resistance after denervation may be fiber type dependent; it was detected earlier and appeared more severe in soleus and plantaris muscles than in gastrocnemius in in vivo studies (6). Although glucose transport was not measured in the present study, correlation with previous work suggests that the effect of denervation on the insulin resistance of glucose transport precedes changes in the expression of glucose transporter isoforms. Furthermore, in 24$\mathrm{h}$-denervated rat soleus muscles, the insulin resistance of glucose transport is reversible in vitro, in the absence of protein synthesis (37), again suggesting that this condition does not reflect a reduction in the total glucose transporter pool.

We did find, however, a decrease in GLUT-4 and an increase in GLUT-1 mRNA and protein in muscle tissue $3 \mathrm{~d}$ after denervation. Maximal insulin resistance of glucose transport is not achieved until $3 \mathrm{~d}$ after denervation when assayed in vitro $(5,38,39)$ or in vivo $(6)$. In addition, in vivo studies of gastrocnemius and plantaris muscles, reported increased basal glucose transport $3 \mathrm{~d}$ after denervation; some of the effects were fiber type dependent $(6,40)$. Although both glucose transporter isoforms are capable of insulin-stimulated translocation, GLUT-1 is thought to reside primarily in the plasmalemma and to contribute mainly to basal glucose transport, whereas in the basal state, GLUT-4 resides primarily in intracellular vesicles, which translocate to the plasma membrane in response to insulin (2, $3,9)$. An increase in the concentration of GLUT-1 $3 \mathrm{~d}$ postdenervation could therefore contribute to enhanced basal glucose transport (6). Similarly, the $\sim 50 \%$ decrease in the total GLUT-4 protein pool, may contribute to the increased severity of the insulin resistance of denervated muscles after $3 \mathrm{~d}$. The lack of change in total glucose transporter number early after denervation, does not preclude the existence of changes in their subcellular distribution, intrinsic activity, or affinity for glucose. Because concommitantly with its effect on glucose transport, denervation also causes insulin resistance of other insulin-responsive pathways in muscle, i.e., glucose-independent activation of glycogen synthase $(4,5)$ and amino acid transport (6), it is tempting to speculate that denervation may impair signal transduction between the activated insulin receptor and some early response element(s) $(37,38)$. Similarly to the present observations in denervated muscles, in muscles of streptozotocin diabetic rats, the insulin resistance of glucose transport precedes reductions in GLUT-1 and GLUT-4 protein (22).

The observed decrease in GLUT-4 mRNA abundance may represent transcriptional regulation or changes in mRNA stability. After denervation total RNA and protein decrease in parallel, however, discoordinate regulation for the synthesis of several muscle proteins has been reported (41-44). GLUT-4 is the major glucose transporter isoform expressed in skeletal muscle (1-3). Our data indicate that it belongs to the group of muscle mRNAs and proteins which decrease after denervation; it was reduced by $\sim 50 \%$, similar to $\alpha$-skeletal muscle actin mRNA ([36, 41] and Fig. 2).

The cell-type responsible for the increased expression of GLUT-1 was not identified in these studies. After denervation of vertebrate skeletal muscle interstitial cells undergo a transient proliferative response, which peaks on days $2-4$ and is not accompanied by infiltration of inflammatory cells (45). This well characterized but poorly understood phenomenon is thought to represent a limited regenerative response, which may be elicited by trophic factors released by degenerating axons, Schwann cells and denervated muscle fibers (45-47).
Satellite cell proliferation is minimal within 1 wk after denervation $(45,46)$. Among the cell types that occupy interstitial spaces between muscle fibers are Schwann cells, perineurial cells, capillary endothelial cells, and fibroblasts, the latter are considered the major participants in mitosis $(45,47)$. Fibroblast proliferation occurs preferentially near synaptic junctions, which comprise $<0.1 \%$ of muscle surface area (47) but has been observed along the entire length of muscle fibers (45). Due to their small size, interstitial cells comprise a small portion of total muscle mass, but represent $\sim 40 \%$ of total muscle DNA (45). In the present study, on the third day after denervation, GLUT-1 mRNA had increased sixfold, yet we observed no significant increase in DNA content per gram muscle (Table I). Therefore, it seems less likely that the observed increase in GLUT-1 mRNA represented merely an increase in the number of interstitial cells (which presumably express GLUT-1 constitutively) rather than increased expression of GLUT-1 by some type(s) of interstitial cells and/or muscle cells.

Immunofluoresence studies of innervated rat diaphragms indicate that GLUT-1 is most abundant in the perineurial sheath of cells surrounding nerve fibers (48). In preliminary, immunocytochemical studies (data not shown) we confirmed the above observation in control and in $3 \mathrm{~d}$ denervated rat hindlimb muscles. Whereas cells comprising the perineurial sheath were clearly immunostained by the anti-GLUT-1 antibody, our methods lacked the sensitivity to identify GLUT-1 in muscle cells, or to identify site(s) of increased immunostaining in denervated muscle. (Note that whereas GLUT-1 mRNA concentration had increased sixfold, the concentration of GLUT-1 protein in total cell membranes [Table II] had increased by only $\sim 60 \% 3 \mathrm{~d}$ after denervation.)

Although we have no direct evidence to indicate that the increase in GLUT-1 expression after denervation occurred in muscle cells, this would be consistent with other known effects of denervation on muscle gene expression. Denervation induces dramatic reexpression of embryonic or neonatal isoforms of several skeletal muscle mRNAs or proteins, including $\alpha$-cardiac actin, myosin heavy chain, the $\alpha$-subunit of the acetylcholine receptor and a voltage-sensitive sodium channel (41-44). Developmental studies suggest that this phenomenon reflects the absence of selective gene repression by nerve stimuli (41-44). The increase in GLUT-1 mRNA could reflect, in part, a generalized dedifferentiation response of muscle to denervation, even though this response is usually not biphasic (41-44). Whereas it is not known that GLUT-1 is the embryonic form of the glucose transporter in skeletal muscle, it is the predominant isoform expressed in muscle-derived cell lines (3, $49,50)$. In the L-6 muscle cell line, GLUT-1 is the major and GLUT-4 the minor glucose transporter isoform; the expression of the two isoforms appears to be differentially regulated (49). GLUT-1 decreases while GLUT-4 increases in the course of differentiation in L-6 cells, whereas basal glucose transport decreases and insulin responsiveness increases concommitantly (50). Similarly, GLUT-4 mRNA is induced during differentiation of NIH 3T3-L1 preadipocytes to adipocytes, and increases in parallel with the insulin response of glucose transport; GLUT-1 mRNA is unchanged $(51,52)$ or decreases concommitantly (53). In parallel with GLUT-4 mRNA induction, differentiating adipocytes also acquire the ability to segregate glucose transporter isoforms into miscrosomes and to translocate them to the cell membrane in response to insulin or IGF-1 (51).

The biphasic time course of GLUT-1 mRNA expression in 
denervated skeletal muscle tissue suggests the possible involvement of trophic factors. In cell culture systems, GLUT-1 mRNA increases in response to growth factors including insulin, PDGF, FGF, and phorbol esters (3, 9, 10-14). Denervated muscle cells and/or degenerating nerve fibers may release insulinlike or other growth factors into interstitial spaces (54) which may induce GLUT-1 mRNA expression as well as fibroblast proliferation at synaptic junctions.

The decrease in GLUT-4 protein after denervation essentially paralleled changes in the concentration of its mRNA, suggesting that in denervated muscle GLUT-4 protein expression is regulated by mRNA availability. In contrast, the lack of quantitative or temporal parallelism between the increases in GLUT-1 mRNA and protein in denervated muscle tissue (compare Fig. 2 and Table II) suggests a more complex regulation of GLUT-1 protein expression. This could involve processing or translation of the message or processing and/or degradation of GLUT-1 protein. Posttranscriptional regulation of GLUT-1 expression has been observed in cultured fibroblasts (55) and neuronal cells (14).

Whereas there is convincing evidence for the differential regulation of GLUT-1 and GLUT-4 expression in adipocytes $(9,18-21,23,51-53,56)$ and in a muscle-derived cell line (49, $50)$, there is less information concerning their regulation in skeletal muscle tissue $(3,9)$. Fasting $(23)$ and insulinopenic diabetes (22) affect GLUT-1 and GLUT-4 expression by rat muscle tissue in parallel, both increase with fasting and decrease with diabetes. In contrast, the expression of GLUT-1 and GLUT-4 in skeletal muscle tissue is affected differentially by denervation; the decrease in GLUT-4 expression most likely occurs almost exclusively in muscle cells (adipocytes in muscle tissue may be minor contributors), whereas the increased expression of GLUT-1 may primarily involve interstitial cells and/or muscle cells. The expression of glucose transporter isoforms in skeletal muscle tissue may be controlled in part by nervous stimuli and/or contractile activity. A decrease in skeletal muscle GLUT-4 may contribute to the impaired glucose tolerance with insulin resistance frequently observed in patients with spinal cord injuries and other neuromuscular disorders (56 and references therein, 57).

\section{Acknowledgments}

We are grateful to Dr. Graeme I. Bell (Howard Hughes Medical Institute and Departments of Biochemistry and Molecular Biology and Medicine, University of Chicago) for the generous gifts of plasmids encoding GLUT- 1 and GLUT-4 cDNA's; to Dr. Amira Klip (Department of Cell Biology, the Hospital for Sick Children, University of Toronto) for the gift of site-specific anti-GLUT-4 antibody and helpful discussion; to Dr. Jeffrey E. Pessin (Department of Physiology and Biophysics, University of Iowa) for methodological advice concerning muscle membrane preparation; and to Dr. Bradley A. Schulte (Department of Pathology, MUSC) for permission to discuss immunocytochemical studies which are in progress. We thank Ms. Debra Riebe for expert secretarial assistance.

This work was supported in part by National Institute of Diabetes and Digestive and Kidney Diseases grant DK-02001 (to M. G. Buse), and a postdoctoral fellowship from the American Diabetes Association (to N. E. Block).

Note added in proof: A 52\% reduction in GLUT-4 protein was recently reported in rat soleus muscles $3 \mathrm{~d}$ after denervation (59).

\section{References}

1. Bell, G. I., T. Kayano, J. B. Buse, C. F. Burant, J. Takeda, D. Lin, H. Fukumoto, and S. Seino. 1990. Molecular biology of mammalian glucose transporters. Diabetes Care. 13:198-208.

2. Kasanicki, M. A., and P. F. Pilch. 1990. Regulation of glucose transporter function. Diabetes Care. 13:219-227.

3. Klip, A., and M. R. Paquet. 1990. Glucose transport and glucose transporters in muscle and their metabolic regulation. Diabetes Care. 13:228-243.

4. Burant, C. F., S. K. Lemmon, M. K. Treutelaar, and M. G. Buse. 1984 Insulin resistance of denervated rat muscle a model for impaired receptor-function coupling. Am. J. Physiol. 247:E657-E666.

5. Smith, R. L., and J. C. Lawrence. 1984. Insulin action in denervated rat hemidiaphragms. Decreased hormonal stimulation of glycogen synthesis involves both glycogen synthase and glucose transport. J. Biol. Chem. 259:22012207.

6. Turinsky, J. 1987. Dynamics of insulin resistance in denervated slow and fast muscles in vivo. Am. J. Physiol. 252:R531-R537.

7. Burant, C. F., M. K. Treutelaar, and M. G. Buse. 1986. In vitro and in vivo activation of the insulin receptor kinase in control and denervated skeletal muscle. J. Biol. Chem. 261:8985-8993.

8. Seider, M. J., W. F. Nicholson, and F. W. Booth. 1982. Insulin resistance for glucose metabolism in disused soleus muscle of mice. Am. J. Physiol. 242:E12-E18.

9. Kahn, B. B., and J. S. Flier. 1990. Regulation of glucose transporter gene expression in vitro and in vivo. Diabetes Care. 13:548-564.

10. Rollins, B. J., E. D. Morrison, P. Usher, and J. S. Flier. 1988. Platelet-derived growth factor regulates glucose transporter expression. J. Biol. Chem. 263:16 523-16 526.

11. Herreros, A. G., and M. J. Birnbaum. 1989. The regulation by insulin of glucose transporter gene expression in 3T3 adipocytes. J. Biol. Chem. 264:98859890.

12. Hiraki, Y., O. M. Rosen, and M. J. Birnbaum. 1988. Growth factors rapidly induce expression of the glucose transporter gene. J. Biol. Chem. 263:13 655-13 662 .

13. Kitagawa, T., M. Tanaka, and Y. Akamatsu. 1989. Regulation of glucose transport activity and expression of glucose transporter mRNA by serum, growth factors and phorbol esters. Biochim. Biophys. Acta. 980:100-108.

14. Mudd, L. M., H. Werner, Z. Shen-Orr, C. T. Roberts, Jr., D. LeRoith, H. C. Haspel, and M. K. Raizada. 1990. Regulation of rat brain/HepG2 glucose transporter gene expression by phorbol esters in primary cultures of neuronal and astrocytic glial cells. Endocrinology. 126:545-549.

15. Walker, P. S., J. A. Donovan, B. G. Van Ness, R. E. Fellows, and J. E. Pessin. 1988. Glucose-dependent regulation of glucose transport activity, protein and mRNA in primary cultures of rat brain glial cells. J. Biol. Chem. 623:15 59415601 .

16. Birnbaum, M. J., H. C. Haspel, and O. M. Rosen. 1987. Transformation of rat fibroblasts by FSV rapidly increases glucose transporter gene transcription. Science (Wash. DC). 235:1495-1498.

17. Hiraki, V., A. G. Herreros, and M. J. Birnbaum. 1989. Transformation stimulates glucose transporter gene expression in the absence of protein kinase $\mathrm{C}$. Proc. Natl. Acad. Sci. USA. 86:8252-8256.

18. Kahn, B. B., M. J. Charron, H. F. Lodish, S. W. Cushman, and J. S. Flier 1989. Differential regulation of two glucose transporters in adipose cells from diabetic and insulin-treated diabetic rats. J. Clin. Invest. 84:401-404.

19. Garvey, W. T., T. P. Huecksteadt, and M. J. Birnbaum. 1989. Pretranslational suppression of an insulin-responsive glucose transporter in rats with diabetes mellitus. Science (Wash. DC). 245:60-63.

20. Sivitz, W. I., S. L. DeSautel, T. Kayano, G. I. Bell, and J. E. Pessin. 1989. Regulation of glucose transporter messenger RNA in insulin-deficient states. $\mathrm{Na}$ ture (Lond.). 340:72-74.

21. Berger, J., C. Biswas, P. O. Vicario, H. V. Strout, R. Saperstein, and P. F Pilch. 1989. Decreased expression of the insulin-responsive glucose transporter in diabetes and fasting. Nature (Lond.). 340:70-72.

22. Kahn, B. B., L. Rossetti, H. F. Lodish, and M. J. Charron. 1991. Decreased in vivo glucose uptake but normal expression of GLUT 1 and GLUT 4 in skeletal muscle of diabetic rats. J. Clin. Invest. 87:2197-2206.

23. Charron, M. J., and B. B. Kahn. 1990. Divergent molecular mechanisms for insulin-resistant glucose transport in muscle and adipose cells in vivo. J. Biol. Chem. 265:7994-8000.

24. James, D. E., M. Strube, and M. Mueckler. 1989. Molecular cloning and characterization of an insulin-regulatable glucose transporter. Nature (Lond.). 338:83-87.

25. Birnbaum, M. J., H. C. Haspel, and O. M. Rosen. 1986. Cloning and characterization of a cDNA encoding the rat brain glucose-transporter protein. Proc. Natl. Acad. Sci. USA. 83:5784-5788.

26. Haspel, H. C., M. G. Rosenfeld, and O. M. Rosen. 1988. Characterization of antisera to a synthetic carboxyl-terminal peptide of the glucose transporter protein. J. Biol. Chem. 263:398-403. 
27. Chomczynski, P., and N. Sacchi. 1987. Single step method of RNA isolation by acid guanidinium thiocyanate-phenol-chloroform extraction. Anal. Biochem. 162:156-159.

28. Waterborg, J. H., and H. R. Mathews. 1986. The Burton assay for DNA. Methods Mol. Biol. 2:1-3.

29. Fukumoto, H., T. Kayano, J. B. Buse, Y. Edwards, P. F. Pilch, G. I. Bell, and S. Seino. 1989. Cloning and characterization of the major insulin-responsive glucose transporter expressed in human skeletal muscle and other insulin responsive tissues. J. Biol. Chem. 264:7776-7779.

30. Feinberg, A., and B. Vogelstein. 1983. A technique for radiolabelling DNA restriction endonuclease fragments to high specific activity. Anal. Biochem. 132:6-13.

31. Gunning, P., T. Mohun, S.-Y. Ng, P. Ponte, and L. Kedes. 1989. Evolution of the human sarcomeric-actin genes: evidence for units of selection within the 3' untranslated region of the mRNA's. J. Mol. Evol. 20:202-214.

32. Klip, A., T. Ramlal, D. A. Young, and J. O. Holloszy. 1987. Insulin-induced translocation of glucose transporters in rat hindlimb muscles. FEBS (Fed. Eur. Biochem. Soc.) Lett. 224:224-230.

33. Bradford, M. M. 1976. A rapid sensitive method for quantitation of microgram quantities of protein utilizing the principle of protein-binding. Anal. Biochem. 72:248-254.

34. Laemmli, V. K. 1970. Cleavage of structural proteins during the assembly of the head of bacteriophage T4. Nature (Lond.). 227:571-578.

35. Flier, J. S., M. Mueckler, A. L. McCall, and H. F. Lodish. 1987. Distribution of glucose transporter messenger RNA transcripts in tissues of rat and man. J. Clin. Invest. 79:657-661.

36. Babij, P., and F. W. Booth. 1988. $\alpha$-Actin and cytochrome c mRNAs in atrophied adult rat skeletal muscle. Am. J. Physiol. 254:C651-C656.

37. Sowell, M. O., S. L. Dutton, and M. G. Buse. 1989. Selective in vitro reversal of the insulin resistance of glucose transport in denervated rat skeletal muscle. Am. J. Physiol. 257:E418-E425.

38. Sowell, M. O., K. P. Boggs, K. A. Robinson, S. L. Dutton, and M. G. Buse. 1991. Effects of insulin and phospholipase $C$ in control and denervated rat skeletal muscle. Am. J. Physiol. 260:E247-E256.

39. Buse, M. G., and J. Buse. 1961. The effect of denervation and insulin on the penetration of d-xylose into rat hemidiaphragms. Diabetes. 10:134-141.

40. Turinsky, J. 1987. Glucose and amino acid uptake by exercising muscles in vivo: effect of insulin, fiber population and denervation. Endocrinology. 121:528-535.

41. Shih, H. T., M. S. Wathen, H. B. Marshall, J. M. Caffrey, and M. D. Schneider. 1990. Dihydropyridine receptor gene is regulated by inhibitors of myogenesis and is relatively insensitive to denervation. J. Clin. Invest. 85:781789.

42. Schiaffino, J., L. Gorza, G. Pitton, L. Saggin, S. Ausoni, S. Sartore, and T. Lomo. 1988. Embryonic and neonatal myosin heavy chain in denervated and paralyzed rat skeletal muscle. Dev. Biol. 127:1-11.

43. Gu, Y., and Z. W. Hall. 1988. Immunological evidence for a change in subunits of the acetylcholine receptors in developing and denervated rat muscle. Neuron. 1:117-125.
44. Kaller, R. G., Z. H. Sheng, J. Yang, L. Chen, R. B. Rogart, and R. L. Barchi. 1990. Primary structure and expression of a sodium channel characteristic of denervated and immature rat skeletal muscle. Neuron. 4:233-242.

45. Murray, M. A., and N. Robbins. 1982. Cell proliferation in denervated muscle: identity and origin of dividing cells. Neuroscience. 7:1823-1833.

46. Snow, M. H. 1983. A quantitative ultrastructural analysis of satellite cells in denervated fast and slow muscle of the mouse. Anat. Rec. 207:593-604.

47. Gutchalian, C. L., M. Schachner, and J. R. Sanes. 1989. Fibroblasts that proliferate near denervated synaptic sites in skeletal muscle synthesize the adhesive molecules tenascin (JI), N-CAM, fibronectin and a heparin sulfate proteoglycan. J. Cell Biol. 108:1873-1890.

48. Froehner, S. C., A. Davies, S. A. Baldwin, and G. E. Lienhard. 1988. The blood-nerve barrier is rich in glucose transporter. J. Neurocytol. 17:173-178.

49. Koivisto, U.-M., H. Martinez-Valdes, P. J. Bilan, E. Burdett, T. Ramlal, and A. Klip. 1991. Differential regulation of GLUT-1 and GLUT-4 glucose transport systems by glucose and insulin in L-6 muscle cells in culture. J. Biol. Chem. 266:2615-2621.

50. Mitsumoto, Y., E. Burdett, A. Grant, and A. Klip. 1991. Differential expression of the GLUT1 and GLUT4 glucose transporters during differentiation of L-6 muscle cells. Biochem. Biophys. Res. Commun. In press.

51. Kaestner, K. H., R. J. Christy, J. C. McLenithan, L. T. Braiterman, P. Cornelius, P. H. Pekala, and M. D. Lane. 1989. Sequence, tissue distribution and differential expression of mRNA for a putative insulin-responsive glucose transporter in mouse 3T3-L1 adipocytes. Proc. Natl. Acad. Sci. USA. 86:3150-3154.

52. Weiland, M., A. Schurmann, W. E. Schmidt, and H. Joost. 1990. Development of the hormone-sensitive glucose transport activity in differentiating 3T3L1 murine fibroblasts. Biochem. J. 270:331-336.

53. Tordjman, K. M., K. A. Leingang, D. E. James, and M. M. Mueckler. 1989. Differential regulation of two distinct glucose transporter species expressed in 3T3-L1 adipocytes: effects of chronic insulin and tolbutamide treatment. Proc. Natl. Acad. Sci. USA. 86:7761-7765.

54. Hansson, H. A., B. Rozell, and A. Skottner. 1987. Rapid axoplasmic transport of insulin-like growth factor $I$ in the sciatic nerve of adult rats. Cell. Tissue Res. 247:241-247.

55. Haspel, H. C., E. W. Wilk, M. J. Birnbaum, S. W. Cushman, and O. M Rosen. 1986. Glucose deprivation and hexose transporter polypeptides of murine fibroblasts. J. Biol. Chem. 261:6778-6779.

56. Tai, P. K., J. F. Liao, E. H. Chen, J. Dietz, J. Schwartz, and C. Carter-Su. 1990. Differential regulation of two glucose transporters by chronic growth hormone treatment of cultured 3T3-F442A adipose cells. J. Biol. Chem. 265:21 82821834.

57. Duckworth, W. C., S. S. Solomon, P. Jallepalli, C. Heckemeyer, J. Finnern, and A. Powers. 1980. Glucose intolerance due to insulin resistance in patients with spinal cord injuries. Diabetes. 29:906-910.

58. National Diabetes Data Group. 1979. Classification and diagnosis of diabetes mellitus and other categories of glucose intolerance. Diabetes. 28:10391057.

59. Henriksen, E. J., K. J. Rodnick, C. E. Mondon, D. E. James, and J. O. Holloszy. 1991. Effect of denervation or unweighting on GLUT-4 protein in rat soleus muscles. J. Appl. Physiol. 70:2322-2327. 